understand the nature of the scientific man and his methods-he is just a little too sweeping in his condemnation of the reading list provided in the A.S.W. pamphlet, and he might have strengthened his case by a reference to the "Source Books in the History of Sciences" published by the McGraw-Hill Book Co., which within their limits overcome the difficulty of accessibility to which Dr. Taylor refers.

\section{Colonial Geological Surveys of Africa}

Sir Edmund Teale's important address on "The Contribution of Colonial Geological Survey to the Development of the Mineral and other Resources of East and West Africa", delivered before the Royal Society of Arts, is published in the Society's Journal of April 13, 1945, pp. 245-56. The success of the early mineral surveys, of which the first was started in Nigeria in 1903, made it clear that larger staffs and fuller facilities for the wide extension of geological work on more systematic lines would be amply justified. The first permanent Geological Survey was started on the Gold Coast in 1910, to be followed in 1918 by one in Nigeria, and later by others in Uganda, Tanganyika, Nyasaland, Sierra Leone and Kenya. Their economic activities are summarized as $(a)$ exploratory: dealing essentially with investigations which yield results in the actual discovery of new deposits of minerals, or in mapping the geological features which assist prospectors or mining engineers to locate and open up mineral occurrences; and (b) advisory : including numerous forms of assistance regarding engineering, industrial, commercial, agricultural and welfare interests (for example, water supply, soil conservation and site locations). Much of this assistance, though it has far-reaching influence on colonial development, does not usually lend itself to statistical valuation.

On the exploratory side, however, actual mineral discoveries by Survey geologists have yielded direct revenue in royalties alone which have repaid many times over the total cost of all the Colonial Geological Surveys. The cumulative values, of some of the more important Survey discoveries are as follows (up to 1939 or 1940) :

$\begin{array}{llr}\text { Gold Coast } & \text { Diamonds } & \mathfrak{1 7 , 6 1 3 , 1 8 6} \\ \text { Sierra Leone } & \text { Manganese ore } & 10,062,594 \\ & \text { Iron ore } & 2,640,966 \\ \text { Nigeria } & \text { Diamonds } & 4,700,272 \\ \text { Coal } & 1,860,000\end{array}$

Certain other minerals, such as mica, tin and tungsten ores, and above all bauxite (of which the estimated reserves are 250 million tons in the Gold Coast and 60 million tons in Nyasaland), have afforded important supplies to the strategic mineral requirements of the War.

\section{High Polymer Bulletin}

AnYone familiar with present developments on the academic side of micro-molecular chemistry and physics cannot fail to be impressed by the contributions made to the subject by Prof. H. Mark, now of the Polytechnic Institute, Brooklyn, New York. In this Institute there has been established a Bureau of High-Polymer Research, the business of which is to carry out research on all problems of high-polymer chemistry and to organize and to conduct courses of instruction and also discussions on various aspects of the subject. In order to let the scientific public know more about the activities of the Bureau than would be gleaned by reading papers in the scientific journals, a Polymer Bulletin, issued bi-monthly, has made its appearance under the editorship of Paul M.
Doty. The first number gives a brief description of some of the equipment of the laboratory and of the researches now in progress, but not yet published in the usual journals. While this preview of what is to come from the laboratory is of great interest to highpolymer chemists, it is somowhat unusual, and incidentally an interesting experiment, to find an academic laboratory publishing its own 'science news'. Thus yet another publication is added to the list which a busy investigator must scan to make sure that his own work is not likely to be out of date before it is published. In a quickly advancing subject like high polymers, at the present stage the desire to found new journals inevitably arises; the measure of success depends upon what support is given to the venture in its initial stages.

\section{The World To-day}

WrTH its last issue, for June 23, the Bulletin of International News has been replaced by a monthly review, The World To-day, and a Chronology of International Events and Documents appearing twice monthly. Each issue of the former will contain "Notes of the Month" and five or six articles. The first issue for July includes five, dealing with the municipal elections in France, the Allied zones of occupation in Germany, Germany and European reconstruction, international air transport and Guernsey under German occupation. It is hoped that by articles giving factual background to current international problems and first-hand accounts of conditions in foreign countries, The World To-day will help to meet the demand of the general reader for such factual information; while the Supplement will be for the specialist who requires the reference material in connexion with his work as a student of international affairs, lecturer or writer, business man or diplomat. The new arrangement will also permit the most economical use of the available paper.

\section{Energy Regulators}

THE energy regulator made available by Sunvic Controls, Ltd., operates by periodically switching the power on and off, the ratio on-time/total time determining the average power input. The regulator is generally cheaper and far less bulky than a variable resistance. The control is effected without the energy loss in a resistance, it is variable continuously from no load to full load, and is substantially independent of mains voltage fluctuations up to about 20 per cent. Two forms are available, one for industrial purposes having a minimum time-cycle of about 30 sec., and another for laboratory use with a cycle of about 10 sec. The regulator consists essentially of a bimetal strip carrying a heater winding, connected in parallel with the load to be controlled. A snap action switch is in series with the load and is normally closed, so that current flows through the heater winding and through the load. The bimetal warms up and, in bending, opens the switch, interrupting the current both to the heater winding and the load. The bimetal then cools down and the cycle is repeated. The ratio of the time during which the contacts are made to the total time of the cycle determines the average input.

Some applications of the regulator are as follows : (1) in apparatus where it is inconvenient or impossible to fit a thermostat-for example, hot plates, injection moulding nozzles, moulding platens, etc.; (2) for small, high-temperature ovens and furnaces where 